DOI https://doi.org/10.15589/znp2021.3(486).8

УДК 656.073:656.615

\title{
FEATURES OF DRY PORTS FUNCTIONING IN UKRAINE
}

\section{ОСОБЛИВОСТІ ФУНКЦІОНУВАННЯ СУХИХ ПОРТІВ В УКРАЇНІ}

\author{
Olha I. Petrenko \\ olga_co@meta.ua \\ ORCID: 0000-0002-1869-7999 \\ Anna M. Pashkovich \\ nuta572@ukr.net \\ ORCID: 0000-0003-0598-0581
}

\author{
О. І. Петренко, \\ к.е.н., доцент
}

А. М. Пашкович,
магістр ОПП «Бізнес-логістика»

State University of Infrastructure and Technologies, Kyiv

Державний університет інфраструктури та технологій, Київ

\begin{abstract}
Maritime transport is an important component of Ukraine's economy. Its effective functioning is a necessary factor in the formation of Ukraine as a maritime state, sustainable development of its transport and road complex and the economy as a whole. Maritime transport is the most competitive in Europe. However, the maritime industry of Ukraine is not experiencing the best times.

Seaports of any country play an important role in economic development and commodity circulation in international trade. Despite the widely developed system of seaports, we face a number of unresolved issues. Seaports are the gates of the country that allow the products of our companies to enter international markets or the products of foreign companies to our country. The income of companies that pay taxes to the budget depends on the quality of their work. Seaports are strategic facilities that serve the container market and are able to provide the country with everything it needs and in the shortest possible time, if necessary. Currently, the activities of seaports are quite congested due to lack of sufficient storage facilities, congestion and outdated equipment. There is a question of increasing the competitiveness of seaports and improving the operating environment through the implementation of certain projects. Such a project is the creation of a dry port.

The purpose of the article: to analyze the concept of "dry port", to form its characteristics, functions, tasks, advantages and disadvantages, to summarize the features of dry ports in Ukraine on the basis of international and domestic literature, practical experience.

Results: analyzed characteristics and features of dry port operation, legal processes that accompany its activities.

Scientific novelty of the article: the main features of the concept of "dry port" are generalized, the peculiarities of the dry port functioning in Ukraine are determined, the classic example of a dry port in Ukraine is singled out.

The practical importance of the article is to create a theoretical basis for the development of methods and models for managing the activities of dry ports in Ukraine from the standpoint of the state and society, the further use of which will increase the efficiency of maritime transport in Ukraine.
\end{abstract}

Key words: seaport; dry port; transport and logistics infrastructure; logistics center.

Анотація. Морський транспорт-важлива складова частина економіки України. Його ефективне функціонування $\epsilon$ необхідним чинником становлення України як морської держави, сталого розвитку її транспортно-дорожнього комплексу й економіки в цілому. Морський транспорт є найбільш конкурентоспроможним в Європі. Однак морська галузь України переживає не найкращі часи.

Морські порти будь-якої країни мають важливе значення в економічному розвитку та забезпеченні товарообігу в міжнародній торгівлі. Незважаючи на широко розвинену систему морських портів, перед нами стоїть ряд невирішених проблем. Морські порти - ворота країни, які пропускають продукцію наших підприємств на міжнародні ринки або продукцію іноземних підприємств в нашу країну. Від якості їхньої роботи залежать доходи компаній, які платять податки в бюджет. Морські порти - це стратегічні об’єкти, які обслуговують контейнерний ринок та здатні в разі потреби забезпечити країну всім необхідним і в найкоротший термін. Нині діяльність морських портів $є$ досить перевантаженою через відсутність достатньої кількості складських приміщень, затори та застаріле обладнання. Постає питання щодо підвищення конкурентоспроможності морських портів та поліпшення операційного середовища шляхом реалізації певних проектів. Таким проектом $\epsilon$ створення сухого порту. 
Мета. Мета статті - проаналізувати поняття «сухий порт», сформулювати його характерні риси, функції, завдання, переваги та недоліки, узагальнити особливості функціонування сухих портів в Україні на основі міжнародної та вітчизняної літератури, практичного досвіду.

Результати. Проаналізовано характеристики та особливості функціонування сухого порту, юридичні процеси, які супроводжують його діяльність.

Наукова новизна. Узагальнено основні риси поняття «сухий порт», визначено особливості функціонування сухого порту в Україні, виокремлено класичний приклад сухого порту в Україні.

Практична значимість статті полягає у створенні теоретичного підгрунтя для розроблення методів і моделей управління діяльністю сухих портів на території України з позицій держави та суспільства, подальше використання яких дозволить підвищити ефективність діяльності морського транспорту України.

Ключові слова: морський порт; сухий порт; транспортно-логістична інфраструктура; логістичний центр.

\section{ПОСТАНОВКА ЗАДАЧІ}

У сучасних умовах, коли обсяги міжнародної торгівлі, як і кількість учасників зовнішньоекономічної діяльності, істотно збільшилися, багато портів перестають ефективно справлятися зі своїми функціями. Основною причиною цього є елементарна перевантаженість терміналів, яким для прийому величезної кількості вантажів уже просто не вистачає місця. Впровадження нових технологій обробки вантажів і логістики дозволяє вирішити цю проблему лише частково, а для багатьох портів це вже не є дієвим заходом. Вирішенням даної проблеми може стати створення «сухих портів», які набули широкого розвитку в міжнародній практиці.

\section{АНАЛІЗ ОСТАННІХ ДОСЛІДЖЕНЬ І ПУБЛІКАЦІЙ}

У науковій літературі широко вивчається поняття «сухий порт». Аналіз даного питання було проведено Trainaviciute, Laugesen, Kent Bentzen, Roso V., J. Woxenius та K. Lumsden [1; 2]. Функції сухих портів вивчали Rodrigue, Notteboom [3]. Недоліки висвітлили Hanaoka, Regmi, Roso, Lumsden [2; 4; 5].

\section{ВІДОКРЕМЛЕННЯ НЕ ВИРІШЕНИХ} РАНІШЕ ЧАСТИН ЗАГАЛЬНОЇ ПРОБЛЕМИ

Незважаючи на значну кількість публікацій, не існує однозначності у визначенні поняття та розумінні особливостей функціонування сухих портів в Україні. Існує певна плутанина між поняттями «логістичний центр», «логістичний парк», «припортовий термінал», «внутрішнє контейнерне депо», «внутрішній термінал» та «сухий порт». Останнім часом в Україні будь-який логістичний центр починають називати «сухим портом». Однак дана думка $€$ помилковою та підлягає детальному вивченню.

\section{МЕТА ДОСЛІДЖЕННЯ}

Проаналізувати поняття «сухий порт», сформулювати його характерні риси, функції, завдання, переваги та недоліки, узагальнити особливості функціонування сухих портів в Україні.

\section{МЕТОДИ, ОБ'ЄКТ \\ ТА ПРЕДМЕТ ДОСЛІДЖЕННЯ}

Методи дослідження: методи порівняння, аналізу та синтезу, узагальнення, конкретизації.
Об'єкт дослідження - процес функціонування сухих портів на території України.

Предметом дослідження $є$ сукупність теоретичних та практичних засад щодо діяльності сухих портів в Україні.

\section{ОСНОВНИЙ МАТЕРІАЛ}

Не існує єдиної думки щодо визначення поняття «сухий порт» у всьому світі, незважаючи на те, що вже понад 20-ти років фахівці морської галузі оперують ним. Його можна вважати аналогом термінів «припортовий термінал», «внутрішнє контейнерне депо», «внутрішній термінал», «логістичний парк», «внутрішній порт» та «логістичний центр».

Найперше визначення поняття «сухий порт» датується 1982 роком. У довіднику UNCTAD 1991 року з управління сухими портами сказано, що сухий порт - це депо для митного очищення, розташоване осторонь від морського порту, щоб звільнити морський порт від цього навантаження [1].

Визначення даного терміна можна зустріти в документі «Термінологія комбінованих перевезень», підготовленого Європейською економічною комісією ООН, а саме: сухий порт (dry port) - це внутрішній термінал, який безпосередньо пов'язаний 3 морським портом [6].

Відповідно до визначення В. Росо, сухий порт це сукупність складів тимчасового зберігання, допоміжних будівель, споруд, автомобільних і залізничних шляхів, майданчиків, розташованих за межами території морського порту, пов'язаних між собою і портом єдиним технологічним процесом та інформаційною системою, для здійснення вантажних операцій з товарами та їх тимчасовим зберіганням під митним контролем [2].

А згідно 3 джерелом [7] сухий порт - це інтермодальний термінал, розташований у глибинці, що обслуговує регіон, пов'язаний 3 одним або кількома морськими портами залізничним та/або автомобільним транспортом.

Отже, для всіх наведених визначень характерним для сухого порту є такі риси: 1) розташовується на певній відстані від морського порту, знаходиться на суші; 2) має зв'язок із морським портом через 
транспортну інфраструктуру; 3) розвантажує морський порт та виконує ряд додаткових функцій, які розширюють можливості та спрощують здійснення морських вантажоперевезень для учасників як внутрішньої, так і зовнішньоекономічної діяльності, територіально розташованих на значній відстані від портів.

Сплеск інтересу до сухих портів у світі та в Україні стався разом із масовою контейнеризацією вантажів, що перевозяться морем, у зв'язку зі зростанням розміру суден-контейнеровозів, що доставляють у порти величезні партії контейнерів, які потрібно було «переварити» і забезпечити їх своєчасну доставку у внутрішні регіони. Розпочалося будівництво різноманітних внутрішніх мультимодальних терміналів, контейнерних депо, контейнерних станцій, митних терміналів й інших схожих об'єктів.

Частину з них почали називати сухими портами, оскільки реально туди було винесено багато робіт, які традиційно виконували в морських портах, - митне оформлення, зберігання, перетарювання, перевалка 3 одного виду транспорту на інший тощо.

Сьогодні, на жаль, законодавчо в нашій країні статус припортових терміналів не визначено. С Закон «Про морські порти України», Закон «Про транспортно-експедиторську діяльність», прописано механізми роботи портових операторів, але роботу припортових терміналів поки що нормативно не врегульовано [8].

До основних функцій сухого порту можна віднести:

1. Перевантаження вантажу між різними транспортними засобами. Ця функція вимагає наявності спеціального обладнання в терміналі, щоб мати можливість передавати одиниці товарів 3 одного режиму в інший. Хороша координація перевантажувальних операцій необхідна для того, щоб зробити операції менш трудомісткими. Щодо сухого порту найчастіше це перехід від залізничного до автомобільного транспорту, або навпаки. У виняткових випадках сухий порт може також включати 3'єднання водними шляхами, коли вантаж 3 морського порту до сухого доставляється на баржі [1].

2. Сортування. Коли вантаж перевозиться судном, контейнери повинні бути відсортовані в приймальному порту, оскільки ряд ланцюгів постачання, які мають різні пункти призначення, зосереджені в одному судні. Однак, щоб мати більше місця в зоні порту, яка іноді дуже перевантажена, функції розподілу можна передати на зовнішній термінал - сухий порт [3].

3. Зберігання. Послуга зберігання дуже важлива для транспортних мереж, оскільки деякі регіони отримують більше контейнерів, ніж надсилають, i навпаки. Таким чином, сухі порти можна з'єднати i використовувати для регулювання дисбалансу потоків контейнерів. Зберігання товарів може зайняти різні періоди часу в сухому порту. Якщо він використовується переважно для дистрибуції, товар зберігається тривалий час. Крім того, простір у глибинці сухого порту може бути використаний для тривалого зберігання порожніх контейнерів. Коли товари перевантажуються з одного виду транспорту на інший у сухому порту чи товари підтримуються іншими службами, використовується короткочасне зберігання [1].

4. Управління контейнерними потоками. Питання функцій управління є актуальним, коли сухий порт має зв'язки з кількома відносно близькими і однаковими типами портів (щодо типу вантажу, з яким вони мають справу). Наприклад, коли один порт у певний час зайнятий, щоб прийняти вантаж, маршрутний поїзд може бути направлений до менш завантаженого порту.

5. Консолідація окремих потоків контейнерів. Контейнери різних вантажовідправників можуть транспортуватися до сухого порту з морського порту, завантажуватися в один маршрутний поїзд та транспортуватися до порту або на більш далекі відстані, наприклад з Свропи до Далекого Сходу.

6. Зменшення використання автомобільних засобів та розширення залізничного транспорту. Сухі порти зазвичай з'єднані з морськими портами залізницею. Це дає можливість консолідувати товари різних вантажовідправників у сухому порту та транспортувати їх далі до порту залізницею. Таким чином, сухі порти стимулюють рух залізницею, а не дорогами, що може принести значну екологічну користь.

7. Пропонування спеціальних та додаткових послуг. Одна 3 найважливіших спеціальних послуг - митне оформлення. Митне оформлення в сухому порту значно скорочує час очікування. Зазвичай цей час довгий і спричиняє затори в морському порту. Технічне обслуговування агрегатів також вважається додатковою послугою. Вона є більш актуальною, якщо сухий порт забезпечує зберігання порожніх контейнерів. У сухому порту можуть бути надані також й інші додаткові послуги, такі як складування, послуги з доданою вартістю тощо.

Можна виділити такі завдання сухих портів:

1) виведення за межі досить завантаженої території морського порту діяльності з митного очищення вантажів;

2) звільнення морського порту від необхідності займатися тривалим зберіганням вантажів;

3) звільнення міських вулиць, що примикають до морських портів, від великого числа вантажних автомобілів, які очікують черги потрапити в порт;

4) звільнення від автомобільних заторів прилеглих до портів автострад;

5) консолідація й управління вантажопотоками, передусім контейнерними.

Сухі порти, попри свою корисність, мають як позитивні, так і негативні сторони. Розглянемо їх більш детально. 
Перевагами створення та функціонування сухого порту є:

1) збільшення місткості морського порту;

2) збільшення продуктивності морського порту;

3) зменшення заторів у морських портах;

4) зменшення заторів у містах морських портів;

5) зменшення ризику виникнення дорожньотранспортної пригоди;

6) зменшення впливу на навколишнє середовище;

7) економічний вплив;

8) може виконувати функцію депо;

9) покращує доступ морського порту до територій за межами його традиційної глибинки.

Переваги функціонування сухих портів 3 позицій різних стейкхолдерів (експедиторів, вантажовідправників, портових органів, суспільства, дорожніх та залізничних операторів) можна представити у вигляді таблиці.

Отже, з таблиці видно, що створення сухих портів дозволяє суспільству виграти від балансування між автомобільною та залізничною транспортною системою. Експедитори, вантажовідправники, портові органи та дорожні оператори одержують переваги за рахунок скорочення часу очікування в порту, оскільки їм більше не потрібно затримувати щоденний графік роботи чи надання послуг. 3 точки зору питання заторів на дорогах, експедитори, суспільство та оператори автомобільних доріг мають шанс скористатися цим, оскільки це полегшує поїздки на роботу, автомобільний рух і обслуговування доріг. У міру просування суспільство також отримує більшу користь від «запобігання збільшенню забруднення навколишнього середовища», оскільки сухий порт допомагає зменшити кількість викидів СО2 та інших газів у навколишнє середовище. Вантажовідправники та портові органи також одержують переваги від посилення ролі морських портів у транспортних ланцюгах шляхом з'єднання із сухим портом. Крім того, адміністрація порту виграє внаслідок скорочення використання дорогих територій у порту як для надбудов, так і для інших речей, які можуть потребувати значного використання землі. Нарешті, все суспільство виграє від впровадження сухого порту 3 точки зору створення нових робочих місць.

Але, крім переваг, є й недоліки функціонування сухих портів, а саме:

1) державна політика та її правила. Це пов'язано 3 тим, що створення сухого порту потребує державного розгляду до прийняття остаточного рішення. Державний розгляд передбачає залучення різних міністерств, таких як міністерство навколишнього середовища, інфраструктури, землеустрою та багато інших державних органів [4];

1) вплив на навколишне середовище та суспільство. Дорожні та залізничні перевезення спричиняють такі негативні наслідки, як затори, шум та забруднення повітря;

2) вплив на інфраструктуру. Однією з основних концепцій сухого порту є залізнична інфраструктура, залізничне сполучення між морським портом і сухим портом є основним чинником успіху сухого порту. Залізнична інфраструктура є дротом життя в розвитку сухих портів;

3) фінансові проблеми. Фінансування сухих портів є головною перешкодою, оскільки впровадження сухого порту вимагає значних фінансових ресурсів. Фінансуванню також підлягає нинішня інфраструктура залізниць та автомобільних доріг, щоби впоратися зі зростаючими навантаженнями [5];

4) обмеження користування землею. Обмеження землекористування є головною проблемою для розвитку внутрішніх терміналів у багатьох розвинених країнах. Крім того, коли право власності на землю належить фізичній особі, а не колективно належить уряду, рішення про придбання землі для внутрішнього інтермодального терміналу є дуже складним.

Таблиця 1. Переваги функціонування сухих портів з позицій різних стейкхолдерів

\begin{tabular}{|c|c|c|c|c|c|c|}
\hline Переваги & 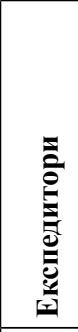 & 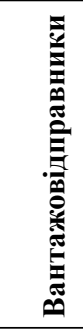 & 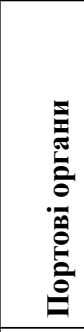 & 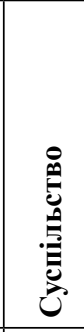 & 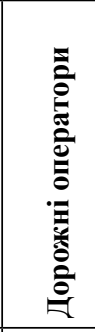 & 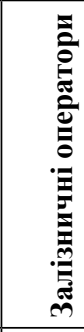 \\
\hline Баланс між автомобільним і залізничним транспортом & & & & + & & + \\
\hline Коротший час очікування в порту & + & + & + & & + & \\
\hline Зменшення заторів на дорогах & + & & & + & + & \\
\hline Запобігання збільшенню забруднення навколишнього середовища & & & & + & & \\
\hline Посилення ролі морських портів у транспортних ланцюгах & & + & + & & & \\
\hline Скорочення використання дорогих територій у порту & & & + & & & \\
\hline Створення нових робочих місць & & & & + & & \\
\hline
\end{tabular}

Джерело: побудовано авторами на основі [1] 
Оскільки сухі порти можуть виконувати функції логістичних центрів 3 перевалки морських вантажів на внутрішніх напрямках, зберігання та митного оформлення товарів, то окремо розглянемо основні юридичні моменти роботи терміналів такого формату в Україні.

Перед сухим портом стоїть завдання забезпечити безперервне та ефективне функціонування інфраструктури. Для цього потрібно коректно вибудувати правовідносини щодо користування інфраструктурою (земельними ділянками, складськими та накопичувальними транзитними майданчиками, складами та іншими спорудами), митного оформлення вантажів, а також 3 автомобільними перевізниками і залізницею.

Питання користування інфраструктурою варто вирішити ще на етапі створення сухого порту. Так, власнику сухого порту потрібно організувати взаємини із власником земельної ділянки, на якому буде знаходитися сухий порт, за необхідності - 3 власниками суміжних земельних ділянок для встановлення сервітутів. Також варто пам'ятати про відповідність цільового призначення земельної ділянки планованої діяльності і про обов'язкове нотаріальне посвідчення договорів користування земельною ділянкою на термін більше 3 -х років.

Щодо інших елементів інфраструктури сухого порту також повинні бути оформлені правовідносини. Власник сухого порту купує або орендує вже існуючі об'єкти або створює їх самостійно. Будівництво інфраструктури - дорогий процес, під час якого виникає безліч правовідносин, і вони повинні бути оформлені так, щоб не збільшувати собівартість будівництва.

Ключові переваги сухих портів полягають у тому, що вони безпосередньо взаємодіють із двома основними видами транспорту - залізницею і автомобільним транспортом. В українських реаліях взаємини із залізницею - це завжди відносини 3 держпідприємством «Укрзалізниця», а також із власниками залізничних під'їзних шляхів. Під час експлуатації залізничних під’їзних шляхів, які безпосередньо підходять до сухого порту, виникають договірні відносини між власником під’їзних шляхів і АТ «Укрзалізниця». При цьому власником під’їзних шляхів може бути сам сухий порт, тоді в нього виникають прямі взаємовідносини з АТ «Укрзалізниця», або третя особа - у цьому випадку сухому порту необхідно вибудувати відносини із власником, який у свою чергу взаємодіє з «Укрзалізницею».

Існують такі види договорів, які укладаються між вищевказаними суб'єктами:

1. Договір про подачу та прибирання вагонів. Сторонами договору є АТ «Укрзалізниця» і замовник користувач залізничної колії, в якого немає власного локомотива. АТ «Укрзалізниця» зобов’язується пода- вати під завантаження і вивантаження вагони безпосередньо на під’їну колію і розставляти їх на місцях завантаження і вивантаження, а користувач - приймати ці вагони та здавати їх залізниці, забезпечувати дотримання певного терміну перебування вагонів на під’ізній колії і оплачувати АТ «Укрзалізниця» обумовлену договором плату.

2. Договір про експлуатацію залізничної колії. Цей договір передбачає надання АТ «Укрзалізницею» послуг власнику шляху. Залізниця зобов'язується подавати під навантаження і вивантаження вагони до кордону під’їзої колії, а власник - приймати ці вагони і здавати їх залізниці з виконанням облікових операцій, здійснювати подальший рух вагонів власними або орендованими локомотивами [9].

На думку авторів, в Україні натепер існує тільки один сухий порт, який відповідає класичному визначенню, він має назву «Сухий порт» компанії «Свротермінал» і розташований в Одесі. Компанія «Свротермінал» - інвестиційна та операційна компанія, яка реалізує проект розширення території Одеського морського порту - «Сухий порт». Компанія створена в 2005 році за підтримки Свропейського банку реконструкції та розвитку для забезпечення транспортних зв'язків між Європою і Азією (в рамках Міжнародного транспортного коридору № 9) [10]. «Сухий порт» - це мультимодальний логістичний центр з розвиненою інфраструктурою, в який входять: відкриті складські площі для зберігання контейнерів; накопичувальний транзитний майданчик; склад тимчасового зберігання; комплекс із перероблення збірних вантажів; термінал для зберігання і підвищення якості зернових вантажів; бізнес-центр; «Автохаб»; митний склад; вантажний митний комплекс [11].

Під час створення «Сухого порту» було розплановано можливості подальшого розширення, організації виробництва, а також функціональної взаємодії з усіма видами транспорту. Крім того, він знаходиться в безпосередній близькості від Одеського порту (6 км) та з’єднується з ним естакадою (магістральним шляхопроводом) [12].

До того ж компанія «Свротермінал» завершила будівництво під'їзної залізниці від «Сухого порту» до станції Одеса - Пересип. Пропускна спроможність новозбудованої колії понад 1 млн тонн вантажів на рік. Побудована залізниця дозволяє приймати різну номенклатуру вантажів: контейнери, сипучі та генеральні вантажі. Будівництво нової гілки дозволяє знизити витрати компанії, іiі клієнтів, портових операторів, експедиторів, митних агентів і логістичних операторів, сприяє спрощенню адміністрування всього логістичного ланцюга та спрямована на оптимізацію процесів. У подальших планах компанії - побудова станції з перероблення контейнерних поїздів, контейнерів та комплексу 3 доробки зернових та нішевих культур. Будівництво 
залізничної гілки також дозволить знизити рівень міського трафіку, зменшити кількість вантажного транспорту, що проходить через прохідні порту та естакаду, i, як наслідок, зменшити негативний вплив на довкілля [13; 14].

Поряд із «Сухим портом» компанії «Євротермінал» часто можна зустріти інформацію про сухий порт, або індустріальний парк на Львівщині (Індустріальний парк «Мостиський Сухий порт»), що розміщуватиметься на території між містом Мостиська, залізничною станцією Мостиська-2 і селом Годині [15]. Загальні інвестиції в проект цього сухого порту біля українсько-польського кордону оцінюють у 15 млн дол. США [16].

Ідея будівництва сухого порту у Львівській області не нова. Цей проєкт було анонсовано ще в 2017 році. В уряді України зазначають, що наразі це лише інформаційна пропозиція. Час реалізації проєкту 2026 рік. Його створення пов'язано $з$ державно-приватним партнерством, оскільки передбачається залучення іноземних інвестицій.

Метою будівництва порту є зростання торгівлі між Україною та країнами Свропи. Хаб має покращити логістику для вантажовідправників та знизити ціни на вантажні перевезення [17]. Даний порт буде орієнтуватись на залізничні вантажні перевезення, що допоможе зменшити навантаження на дороги. Його площа буде становити 63 га. Даний логістичний хаб розділять на 15 окремих ділянок або на 9 зон: для обслуговування логістичного комплексу; для обслуговування об'єктів транспортної інфраструктури; для обслуговування промислових i/або наукових об'єктів; для соціального, торговельного обслуговування адміністративного центру i загальних служб; для обслуговування рідиннозернового перевантажувального комплексу; для обслуговування відкритих просторів загального користування; для обслуговування парків; для обслуговування під'їзних колій [15].

Але, досліджуючи інформацію про цей сухий порт, автори дійшли висновку, що даний індустріальний парк все ж таки є логістичним центром, а не сухим портом у класичному розумінні. Це ж стосується й таких багатопрофільних припортових терміналів, як «Ліски-Одеса», «6-й км», «Блек Сі Шиппінг Сервіс», «Іллічівськзовніштранс» тощо.

\section{ОБГОВОРЕННЯ ОТРИМАНИХ РЕЗУЛЬТАТІВ}

Діяльність сухих портів $є$ новим напрямом розвитку транспортної інфраструктури, яка відкриває багато можливостей. Існують три основні причини створення сухих портів у всьому світі, а саме:

1) постійна необхідність підвищення ефективності внутрішнього транспорту;

2) постійно зростаючі затори в сухопутних районах навколо великих портів (й одночасно відсутність доступного резервного простору для обробки підвищеного обсягу контейнерних/вантажних потоків);

3) перетворення судноплавства 3 діяльності «порт - порт» до невід’ємного компоненту з ширшими логістичними операціями.

Однак, незважаючи на їхню користь, можуть виникнути проблеми у правовому регулюванні, що вимагає надалі залучення юристів для створення правової бази відповідного рівня.

\section{ВИСНОВКИ}

Отже, за результатами проведеного дослідження було визначено характерні риси, які притаманні класичному поняттю «сухий порт», узагальнено особливості функціонування сухих портів в Україні 3 урахуванням юридичного складника, підгрунтям яких $є$ систематизація практичного та теоретичного досвіду.

Виявлено, що в Україні функціонує лише один сухий порт, що відповідає класичному поняттю, а саме: «Сухий порт» компанії «Свротермінал», а всі інші багатопрофільні припортові термінали, наприклад, «Ліски-Одеса», «6-й км», «Блек Сі Шиппінг Сервіс», «Іллічівськзовніштранс», за своїми характеристиками потрібно віднести до логістичних центрів.

Таким чином, правильне розуміння сутності категоріального апарату, особливостей функціонування, задач, переваг та недоліків 3 позицій суспільства та держави дозволить підвищити ефективність діяльності морського транспорту за рахунок упровадження таких нових інфраструктурних проєктів, як сухі порти. Вони виступають оптимальним рішенням для збільшення вантажообігу морських портів, підвищення своєчасності здійснення вантажних перевезень, а так само подолання екологічних проблем функціонування морських портів.

\section{REFERENCES}

[1] Trainaviciute Lina, Michael Stie Laugesen, and Anthony Caruso Kent Bentzen (2009). The Dry Port - Concept and Perspectives. FDT-Association of Danish Transport and Logistics Centres, July 28. 103 p. [in English]

[2] Hanaoka Shinya and Madan B. Regmi (2011). Promoting Intermodal Freight Transport through the Development of Dry Ports in Asia: An Environmental Perspective. JATSS Research 35, no. 1, July 1. P. 16-23. https://doi.org/10.1016/ j.iatssr.2011.06.001 [in English]

[3] Roso Violeta and Kent Lumsden (2010). A Review of Dry Ports. Maritime Economics and Logistics 12, June 1. P. $196-213$. https://doi.org/10.1057/mel.2010.5 [in English]

[4] Rinat Ahmetov is building a dry port opposite Mostyska 2 station. Resaved from: https://zaxid.net/rinat_ahmetov_pochav_ buduvati_na_lvivshhini_suhiy_port_n1516279 [in Ukrainian] 
[5] What will give the Lviv region a "dry port" in Mostyska. Resaved from: http://tvoemisto.tv/news/shcho_dast_lvivshchyni_ suhyy_port_u_mostyskah_106442.html [in Ukrainian]

[6] Euroterminal has completed the construction of a railway line from the dry port to the Odessa - Peresyp station. Resaved from: https://interfax.com.ua/news/press-release/715709.html [in Russian]

[7] Rodrigue and Notteboom (2011). Dry Ports and the Maritime Hinterland: Gaining Momentum, no. 50, August 30 [in English]

[8] Roso V., Woxenius J. and Lumsden K. (2009). The Dry Port Concept: Connecting Container Seaports with the Hinterland. Journal of Transport Geography, 17(5). P. 338-345. https://doi:10.1016/j.jtrangeo.2008.10.008 [in English]

[9] Combined transport terminology (2001). United Nations: New York and Geneva. $71 \mathrm{p}$.

[10] Dry ports in Ukraine: what, where, when? Port Clearance. Resaved from: https://portclearance.com.ua/blog/suhie-porty [in Ukrainian]

[11] Official website of the company. Resaved from: https://euroterminal.ua/uk/ [in Ukrainian]

[12] Euroterminal has completed the construction of a railway to the port of Odessa. Resaved from: https://www.railinsider.com.ua/ yevroterminal-zavershyv-budivnycztvo-zaliznychnoyi-koliyi-do-odeskogo-portu/ [in Ukrainian]

[13] Why do dry ports not become locomotives of the maritime industry? Resaved from: http://www.golos.com.ua/article/341199 [in Ukrainian]

[14] The dry port in Mostyska is planned to be completed in seven years. Resaved from: https://varianty.lviv.ua/ 72373-sukhyi-port-u-mostyskakh-planuiut-povnistiu-zavershyty-za-sim-rokiv [in Ukrainian]

[15] Roso V. (2009). The Dry Port Concept. Thesis for the degree of doctor of philosophy. Gothenburg: Chalmers University of Technology, $184 \mathrm{p}$.

[16] Dry port. The order of interaction with the railway. Resaved from: https://interlegal.com.ua/ru/publikacii/suhoj_port poryadok_vzaimodejstviya_s_jeleznoj_dorogoj/ [in Russian].

[17] Euroterminal is an investment and operating company. Resaved from: http://www.port.odessa.ua/ru/partnery/sukhoj-port [in Russian].

\section{СПИСОК ВИКОРИСТАНОЇ ЛІТЕРАТУРИ}

[1] Trainaviciute Lina, Michael Stie Laugesen and Anthony Caruso Kent Bentzen. (2009) The Dry Port - Concept and Perspectives. FDT-Association of Danish Transport and Logistics Centres, July 28. 103 p.

[2] Hanaoka Shinya and Madan B. (2011) Regmi. Promoting Intermodal Freight Transport through the Development of Dry Ports in Asia: An Environmental Perspective. JATSS Research 35, no. 1, July 1. P. 16-23. URL: https://doi.org/10.1016/ j.iatssr.2011.06.001.

[3] Roso Violeta and Kent Lumsden. (2010) A Review of Dry Ports. Maritime Economics and Logistics 12, June 1. P. $196-213$. URL: https://doi.org/10.1057/mel.2010.5

[4] Рінат Ахметов будує сухий порт навпроти станції Мостиська II. URL: https://zaxid.net/rinat_ahmetov_pochav_ buduvati_na_lvivshhini_suhiy_port_n1516279

[5] Що дасть Львівщині «сухий порт» у Мостиськах. URL: http://tvoemisto.tv/news/shcho_dast_lvivshchyni_suhyy_port_u_ mostyskah_106442.html

[6] «Евротерминал» достроил железнодорожную ветку от Сухого порта до станции Одесса - Пересыпь. URL: https://interfax.com.ua/news/press-release/715709.html

[7] Rodrigue and Notteboom. (2011) Dry Ports and the Maritime Hinterland: Gaining Momentum, no. 50, August 30.

[8] Roso V., J. Woxenius and K. Lumsden. (2009) The Dry Port Concept: Connecting Container Seaports with the Hinterland. Journal of Transport Geography, 17(5). P. 338-345. URL: https://doi:10.1016/j.jtrangeo.2008.10.008

[9] Терминология комбинированных перевозок. (2001) United Nations: New York and Geneva. 71 p.

[10] Сухие порты в Украине: что, где, когда? PortClearance. URL: https://portclearance.com.ua/blog/suhie-porty

[11] Офіційний сайт компанії. URL: https://euroterminal.ua/uk/

[12] «Свротермінал» завершив будівництво залізничної колії до Одеського порту. URL: https://www.railinsider.com.ua/ yevroterminal-zavershyv-budivnycztvo-zaliznychnoyi-koliyi-do-odeskogo-portu/

[13] Чому сухі порти не стають локомотивами морської галузі? URL: http://www.golos.com.ua/article/341199

[14] Сухий порт у Мостиськах планують повністю завершити за сім років. URL: https://varianty.lviv.ua/72373-sukhyi-portu-mostyskakh-planuiut-povnistiu-zavershyty-za-sim-rokiv

[15] Roso V. (2009) The Dry Port Concept. Thesis for the degree of doctor of philosophy. Gothenburg: Chalmers University of Technology. 184 p.

[16] Сухой порт. Порядок взаимодействия с железной дорогой. URL: https://interlegal.com.ua/ru/publikacii/suhoj_port poryadok_vzaimodejstviya_s_jeleznoj_dorogoj

[17] «Евротерминал»- инвестиционная и операционная компания. URL: http://www.port.odessa.ua/ru/partnery/sukhoj-port

(C) Петренко О. І., Пашкович А. М. Дата надходження статті до редакції: 17.09.2021 Дата затвердження статті до друку: 04.10.2021 